\title{
Does Having a Culturally Competent Health Care Provider Affect the Patients' Experience or Satisfaction? A Critically Appraised Topic
}

\author{
Miranda Brunett and René Revis Shingles
}

\begin{abstract}
Clinical Scenario: The level of cultural competence of health care providers has been studied. However, limited scholarship has examined whether the cultural competence of the health care provider affects patient satisfaction. Focused Clinical Question: Does cultural competence of health care providers influence patient satisfaction with their experience with their provider? Summary of Key Findings: Having a culturally competent health care provider, or one who a patient perceives as culturally competent, does increase patient satisfaction. Clinical Bottom Line: Cultural competence in health care plays an important role in patients being satisfied with their providers, as well as patients willingly and actively participating in their treatment. Strength of Recommendation: Questions 1 to 5 and 9 of the critical appraisal skills program were answered "yes" for all studies in the critically appraised topic. Thus, the authors strongly support the findings.
\end{abstract}

Keywords: cultural competence, patient satisfaction, health care provider, cross-cultural communication, multiculturalism

\section{Clinical Scenario}

People from different cultures, races, ethnicities, genders, sexualities, and other social locations have different beliefs about illness and different needs and preferences when it comes to receiving health care. Cultural competence in health care can generally be defined as the ability of health care providers to have awareness about these differences, as well as to respect them and shift their treatments to the specific needs of their patient. Studies have examined health care provider's level of cultural competence. Some health care providers have received training to become culturally competent or are perceived by their patients as being culturally competent. However, does a health care provider's level of cultural competence influence the provider-patient relationship? Do patients care? Limited studies have examined the effect provider cultural competence has on patient satisfaction. The studies that have examined this show that cultural competence has benefits for the patient.

\section{Focused Clinical Question}

Does having a culturally competent health care provider/staff member (or provider who is perceived to be culturally competent) affect the patients' experience/satisfaction with their provider?

\section{Summary of Search, "Best Evidence" Appraised, and Key Findings}

- We searched for studies that discussed patients' satisfaction with their health care experiences as related to whether they believed their provider (or other staff) to be culturally

The authors are with the Central Michigan University, Mount Pleasant, MI. Shingles (shing1rr@cmich.edu) is corresponding author. competent. To be included, the answers to section A questions 1 to 5 (ie, Are the results of the study valid?) of the critical appraisal skills program (CASP) must be "yes." The answers to section B question 9 (ie, Do you believe the results?) must be "yes," as well. The remaining questions could be "cannot tell" or "no."

- The primary author read 41 articles' abstracts to determine if the article was relevant to our research question. From those 41 abstracts, 18 full articles were read. Five of these articles met our predetermined inclusion criteria and were analyzed in this critically appraised topic (CAT).

- All articles analyzed in this CAT found benefits to health care staff displaying cultural competence, and 1 article reported how a lack of cultural respect worsened the experience of the patients.

\section{Clinical Bottom Line}

\section{Strength of Recommendation}

Questions 1 to 5 and 9 of the CASP were answered "yes" for all studies. Thus, there is strong evidence to suggest that the perceived or actual cultural competence of health care providers/staff has a positive effect on the patients' satisfaction with their experience.

\section{Search Strategy}

We used the following terms to conduct our search:

- Patient/Client group: patient perspective views

- Intervention/Assessment: cultural competency of health care providers, physicians, or staff

- Comparison: no control

- Outcome: patient satisfaction 
Other search term combinations included: "importance to patients of providers being culturally competent"; "importance of cultural competence in health care"; "patients perception of cultural competence"; "discrimination in health care"; "cultural competence $\times$ patient satisfaction"; "physician cultural competence and patient satisfaction"; and "“cultural competence' AND 'patient satisfaction."

\section{Sources of Evidence Searched}

- Google Scholar

- Sage Journals

- Smart Search Central Michigan University

- PubMed

\section{Inclusion and Exclusion Criteria}

\section{Inclusion}

- Studies that examine patients' perspectives of their providers/ health care staff

- Studies had to mention whether patients' perceptions of cultural competence in their health care provider/staff impacted how satisfied the patients were with their experience

- Limited to English language studies between 2005 and 2016

\section{Exclusion}

- Studies that did not focus on the patients' perspective (ie, physicians' or providers' perspective)

- Studies that did not discuss whether cultural competence affected patient satisfaction

- Studies from before 2005

\section{Results of Search}

We found 5 studies $^{1-5}$ that met our predetermined inclusion and exclusion criteria. Each study was independently analyzed using the $\mathrm{CASP}^{6}$ for cohort studies. The CASP for cohort studies is a questionnaire with 12 questions divided into 3 sections (A, B, and C) used for health research. Aside from questions asking what the results and implications of the studies are, as well as how precise the results are, the questions were answered with "yes," "cannot tell," or "no." Section A (questions 1-6) of the questionnaire is used to determine if study results were valid; all of the studies we used appeared valid. Section B (questions 7-9) asked about the results of the study, and section $C$ (questions 10-12) asked whether the results will help locally (see Table 1 for CASP questions and our responses). Although there is limited research done on patient satisfaction and provider cultural competence, the studies examined were either the first of their kind or their results fit with evidence done from other studies. Not all of the results from the studies included in this paper can be generalized to all populations, but the studies used here collectively examined numerous different populations (ie, Latinas, ${ }^{1}$ Southeastern Americans, ${ }^{2}$ individuals with hypertension ${ }^{3}$ ).

\section{Best Evidence}

The studies ${ }^{1-5}$ in Table 2 were selected for inclusion in this CAT. These studies all discussed how patients' experiences with health care were affected by the cultural competence (including perceived cultural competence) of the people giving care. Questions 1 to 5 (section A) and 9 (section B) were all answered "yes." Thus, we believe the studies are valid and the results are believable.

\section{Implications for Practice, Education, and Future Research}

Health care providers, such as nurses, ${ }^{9,10}$ physicians, ${ }^{10}$ and athletic trainers, ${ }^{11}$ have demonstrated various levels of cultural competence. But does the level of cultural competence or perceived cultural competence of the health care provider affect patients' experiences and satisfaction? The most prominent conclusion from this CAT is that cultural competence of health professionals does affect patients' experiences and satisfaction. Not surprising, the more cultural competence a health professional displayed, the more beneficial it was to patients' experiences. Of the 5 articles analyzed, 4 mentioned a variety of benefits patients experienced interacting with culturally competent providers. ${ }^{1,3-5}$ First, more cultural competence resulted in higher patient satisfaction. ${ }^{1,3-5}$ Second, patients tended to be more open with ${ }^{3-5}$ and trusting of ${ }^{4,5}$ the health care staff if the professionals showed cultural competence. Patients who perceived their provider as being culturally competent also were more likely to follow the medical advice of the provider. ${ }^{2,4}$ Additionally, having a provider who could speak the same language as the patient was shown to correlate with higher patient satisfaction. ${ }^{1}$ Conversely, 1 article $^{2}$ reported negative effects of having staff whom were not culturally competent. The participants of this study who identified as European American or African American both perceived age and racial discrimination, felt discriminated against if uninsured, or felt they were treated unfairly by the verbal and nonverbal communication of the nonphysician health care staff. ${ }^{2}$ Helping such staff develop adequate patientcentered care practices could be beneficial in increasing patient satisfaction. ${ }^{2}$

The current study has some limitations that offer opportunities for future research. The studies in this CAT show that increased cultural competence is associated with increased patient satisfaction. This CAT did not discuss, however, how other factors unrelated to provider cultural competence may impact the satisfaction of a patient. Future research could examine the relationships between compounding factors and cultural competence on patient satisfaction. Additionally, the findings of the studies ${ }^{1-5}$ in this CAT cannot be generalized to all populations of people; they focused on narrow populations. Future studies could continue to examine the impacts of cultural competence on other populations of people.

In conclusion, the results of this CAT indicate that cultural competence of health care staff and providers has an influence on patient satisfaction. The more culturally competent a patient considers their provider, the more satisfied the patient. ${ }^{1,3-5}$ Additionally, patients seem to be more willing to comply with their treatment and engage with the provider if the provider is culturally competent. ${ }^{3}$ Becoming culturally competent as an employee in health care, therefore, is beneficial and should be encouraged. This CAT should be repeated after more studies are published on the relationship between cultural competence and patient satisfaction. 


\begin{tabular}{|c|c|c|c|c|c|}
\hline & Castro and Ruiz ${ }^{1}$ & $\begin{array}{l}\text { Ohana and } \\
\text { Mash }^{4}\end{array}$ & Paez et $a^{3}$ & Tajeu et $a^{2}$ & $\begin{array}{l}\text { Thom and } \\
\text { Tirado }^{5}\end{array}$ \\
\hline $\begin{array}{l}\text { Q1. Did the study address a } \\
\text { clearly focused issue? }\end{array}$ & Yes & $\begin{array}{l}\text { Yes; addresses } \\
\text { multiple issues }\end{array}$ & Yes & $\begin{array}{l}\text { Yes; addresses } \\
\text { multiple hypotheses }\end{array}$ & Yes \\
\hline $\begin{array}{l}\text { Q2. Was the cohort recruited in } \\
\text { an acceptable way? }\end{array}$ & Yes & Yes & Yes & Yes & Yes \\
\hline Q3. Was the exposure & Yes & Yes & Yes & Yes & Yes \\
\hline
\end{tabular}

accurately measured to minimize bias?

Q4. Was the outcome accurately measured to minimize bias?

Q5a. Have the authors identified all important confounding factors?

Q5b. Have they taken account of the confounding factors in the design and/or analysis?

Q6a. Was the follow-up of subjects complete enough? Q6b. Was the follow-up of subjects long enough?

Q7. What are the results of this study?

Q8. How precise are the results?

iability alpha coefficients of .88 , $.85, .91$, and .94 found from various questionnaires used (see Table 2).

Correlation scores significant at .05 level

Yes, although not blinded because of of study of education/ barrier; participants often asked a partner to read them questions

Not an ongoing study

See Table 2

See Table 2

Satisfaction of medical care and CC $r=.87$

Gap between physicians' and patients' perception of physicians' CC $r=-.02$

Differences in perceptions and adherence to treatment $r=-.5$
Q9. Do you believe the results?

Q10. Can the results be applied to the local population?

Q11. Do the results of this study fit with other available evidence?

Q12. What are the implications of this study for practice?
Yes

Cannot tell; generalizable to Latina population

Yes, but evidence is limited
Yes

Cannot tell; generalizable to Israelians, Ethiopians, or former Soviet Union populations

Yes

Health care should employ NPs with $\mathrm{CC}$, higher education and ability to speak same language as primary population

Important to have providers be $\mathrm{CC}$, communicate with patient, and share the treatment plan with patient
Not an ongoing study

See Table 2

$\mathrm{OR}=3.1 ; 95 \% \mathrm{CI}$, 1.4-6.9

Not an ongoing study

See Table 2

No CI given $1.4-6.9$

\section{$\begin{array}{lll}\begin{array}{l}\text { Yes; not blinded but } \\ \text { patients kept }\end{array} & \begin{array}{l}\text { Yes, although not } \\ \text { blinded because of }\end{array} & \begin{array}{l}\text { Yes, although not } \\ \text { blinded because of }\end{array}\end{array}$ \\ $\begin{array}{lll}\text { Yes; not blinded but } & \begin{array}{l}\text { Yes, although not } \\ \text { blinded because of }\end{array} & \begin{array}{l}\text { Yes, although not } \\ \text { blinded because of }\end{array}\end{array}$ type of study \\ Yes; considered recall and social desirability biases \\ $\begin{array}{lll}\begin{array}{l}\text { Yes; not blinded but } \\ \text { patients kept }\end{array} & \begin{array}{l}\text { Yes, although not } \\ \text { blinded because of }\end{array} & \begin{array}{l}\text { Yes, although not } \\ \text { blinded because of }\end{array}\end{array}$ \\ $\begin{array}{lll}\text { Yes; not blinded but } & \begin{array}{l}\text { Yes, although not } \\ \text { blinded because of }\end{array} & \begin{array}{l}\text { Yes, although not } \\ \text { blinded because of }\end{array}\end{array}$ type of study \\ Yes; mentioned education level and low rates of insurance and small sample size}

Yes, although not blinded because of type of study

Yes; mentioned low socioeconomic status, low literacy, and limited English of nonrespondents as limitations

Yes

See Table 2

PRPCC found to have construct and predictive validity -patient satisfaction: $r=.32, P<.001$; patient trust: $r=.53, P<.001$; decrease in blood pressure in hypertensive patients: $r=-.18, P<.05$ PSACC less reliable than PRPCC

Yes
Cannot tell; applicable for people in middle to lower class with hypertension and/or diabetes

Not an ongoing study; first study of its kind

Yes

Cannot tell; results are most applicable to people of Southeastern United States

Not an ongoing study; first study to look at satisfaction with nonphysician health staff

Important to patients to have physicians' attitudes and actions be culturally competent
Important for nonphysician staff to be polite to patients and aware of existence of implicit biases
Cannot tell; states that results may not be generalizable

Yes

Appropriate interpersonal behaviors are important in provider cultural competence

Abbreviations: CC, cultural competency; CI, confidence interval; NP, nurse practitioner; OR, odds ratio; PRPCC, Patient-Reported Provider Cultural Competency; PSACC, Provider Self-Assessment of Cultural Competency. 
Table 2 Characteristics of Included Studies

\begin{tabular}{|c|c|c|c|c|c|}
\hline & Castro and Ruiz ${ }^{1}$ & Ohana and Mash ${ }^{4}$ & Paez et $\mathrm{al}^{3}$ & Tajeu et $\mathrm{al}^{2}$ & Thom and Tirado 5 \\
\hline Patients, $\mathrm{n}$ & $\begin{array}{l}218 \text { Latina patients, } \\
\text { most from Mexico and } \\
\text { spoke little/no English } \\
15 \text { female NPs, about } \\
\text { half spoke Spanish, and } \\
93.3 \% \text { had some CC } \\
\text { training }\end{array}$ & $\begin{array}{l}417 \text { patients who speak } \\
\text { Hebrew (56.4\% women, } \\
38.1 \% \text { men, and } 5.5 \% \\
\text { unknown) and } 90 \\
\text { physicians ( } 27.8 \% \text { women, } \\
71.1 \% \text { men, and } 1.1 \% \\
\text { unknown) in outpatient } \\
\text { clinic in Israel }\end{array}$ & $\begin{array}{l}26 \text { PCPs (mean age }= \\
43.6 \mathrm{y}, 42 \% \text { white, } 27 \% \\
\text { African American } 31 \% \\
\text { other, and } 65 \% \text { female) } \\
\text { from Baltimore and } \\
123 \text { patients with } \\
\text { hypertension (mean } \\
\text { age }=61.9 \mathrm{y}, 31 \% \\
\text { white, } 69 \% \text { African } \\
\text { American, and } 64 \% \\
<\$ 35,000 \text { income) }\end{array}$ & $\begin{array}{l}\text { African American }(\mathrm{n}= \\
55,52.7 \% \text { female, mean } \\
\text { age }=49.7 \mathrm{y}, \text { and } 5.6 \% \\
\text { uninsured }[22.2 \% \\
\text { Medicare or Medicaid] }) \\
\text { and European American } \\
(\mathrm{n}=37,49.6 \% \text { female, } \\
\text { mean age }=46.7 \mathrm{y}, \text { and } \\
32 \% \text { uninsured) who } \\
\text { spoke English and had } \\
\text { visited a health care } \\
\text { provider within the past } \\
\text { year }\end{array}$ & $\begin{array}{l}-53 \text { family physicians } \\
\text { (62\% practicing and } \\
38 \% \text { residents, } 45 \% \\
\text { female, mean age }= \\
39.2 \text { y, and } 72 \% \\
\text { white) } \\
\text { - Patients, } \mathrm{n}=429 \\
\text { (age }=58.1(12.0), \\
54.9 \% \text { female, and } \\
26.4 \% \text { white non- } \\
\text { Hispanic) } \\
- \text { Visited physician } \\
\text { within past year for } \\
\text { diabetes and/or } \\
\text { hypertension }\end{array}$ \\
\hline $\begin{array}{l}\text { Experimental } \\
\text { design and } \\
\text { methods }\end{array}$ & $\begin{array}{l}\text { - Descriptive } \\
\text { correlational design } \\
\text { - NPs filled out } \\
\text { demographics } \\
\text { questionnaire and } \\
\text { IAPCC survey } \\
\text { - Patients filled out } \\
\text { demographics } \\
\text { questionnaire, PSQ- } \\
\text { III measuring } \\
\text { satisfaction, and } \\
\text { ARSMA-II } \\
\text { measuring } \\
\text { acculturation }\end{array}$ & 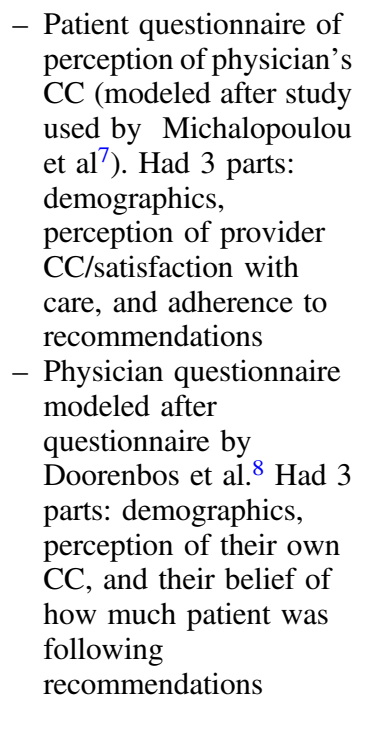 & $\begin{array}{l}\text { Clinical trial: } \\
\text { - PCPs filled out } \\
\text { surveys measuring } \\
\text { usage of components } \\
\text { of CC, motivation to } \\
\text { learn about other } \\
\text { cultures, and } \\
\text { measuring "power } \\
\text { and assimilation" } \\
\text { beliefs } \\
\text { - Patients completed } \\
\text { surveys about } \\
\text { satisfaction, respect } \\
\text { from, and trust in } \\
\text { physician } \\
\text { - Measured patient } \\
\text { participation using } \\
\text { Perception of } \\
\text { Involvement in Care } \\
\text { Scale and a } \\
\text { questionnaire }\end{array}$ & $\begin{array}{l}\text { - } 12 \text { focus groups } \\
\text { examining perception } \\
\text { of discrimination } \\
\text { during primary care } \\
\text { visit } \\
\text { - Participants were in } \\
\text { separate groups based } \\
\text { on race and gender } \\
\text { - Debriefing and } \\
\text { transcribing after } \\
\text { data collection } \\
\text { - Demographic } \\
\text { questionnaire of focus } \\
\text { group participants }\end{array}$ & $\begin{array}{l}\text { - Surveys including } \\
\text { PRPCC given to } \\
\text { patients } \\
\text { - Questionnaire } \\
\text { (PSACC) given to } \\
\text { physicians' } \\
\text { measuring their } \\
\text { ratings of their own } \\
\text { CC } \\
\text { - Results compared } \\
\text { with find reliability/ } \\
\text { validity of PRPCC }\end{array}$ \\
\hline Results & $\begin{array}{l}\text { - Significant } \\
\text { correlation }(r=.193) \\
\text { between CC of NP } \\
\text { and patient } \\
\text { satisfaction } \\
\text { - Correlation between } \\
\text { NP CC and patient } \\
\text { satisfaction with } \\
\text { general care }(r=.16) \\
\text { and interpersonal } \\
\text { aspects of care } \\
\text { - Latina patients prefer } \\
\text { NPs who are Latina } \\
\text { - Highest indicator of } \\
\text { satisfaction was } \\
\text { shorter wait time }\end{array}$ & $\begin{array}{l}\text { - Relationship exists } \\
\text { between physician and } \\
\text { patient cultural } \\
\text { backgrounds and chance } \\
\text { of conflict } \\
\text { - Positive correlations } \\
\text { between patients } \\
\text { satisfaction of care and } \\
\text { patients' perception of: } \\
\text { - cultural knowledge } \\
\text { and competence of } \\
\text { provider }(r=.97 \text { and } \\
r=.87 \text {, respectively) } \\
\text { - patient involvement in } \\
\text { treatment ( } r=.81) \\
\text { - perceived } \\
\text { communication } \\
(r=.80) \\
\text { - Patients view providers } \\
\text { as more CC than } \\
\text { providers view } \\
\text { themselves } \\
\text { - Ethnicity impacts level } \\
\text { of CC they view provider } \\
\text { as having and affects } \\
\text { satisfaction } \\
\text { - Smaller the gap between } \\
\text { physician and patient } \\
\text { perception of CC, the } \\
\text { more patients adhere to } \\
\text { treatment }\end{array}$ & $\begin{array}{l}\text { - Found the more CC } \\
\text { the provider/ } \\
\text { willingness to learn } \\
\text { about other cultures, } \\
\text { the more patient } \\
\text { satisfaction and } \\
\text { openness with } \\
\text { provider } \\
\text { - No relationship } \\
\text { found between } \\
\text { physician CC and } \\
\text { patient trust }\end{array}$ & $\begin{array}{l}\text { - Both races reported } \\
\text { discrimination based } \\
\text { on their racial and } \\
\text { socioeconomic status, } \\
\text { and through verbal and } \\
\text { nonverbal } \\
\text { communication of } \\
\text { nonphysician staff } \\
\text { - European American } \\
\text { reported age } \\
\text { discrimination }\end{array}$ & $\begin{array}{l}\text { - PRPCC had } \\
\text { construct validity } \\
\text { - Moderately } \\
\text { coordinated with } \\
\text { patient } \\
\text { satisfaction and } \\
\text { trust } \\
\text { - Patients reporting } \\
\text { providers giving } \\
\text { behavioral change } \\
\text { suggestions also } \\
\text { reported higher } \\
\text { provider CC } \\
\text { - No correlation found } \\
\text { between patient and } \\
\text { provider reports of } \\
\text { provider CC } \\
\text { - Physician reported } \\
\text { CC not correlated } \\
\text { with patient trust or } \\
\text { satisfaction }\end{array}$ \\
\hline
\end{tabular}


Table 2 (continued)

\begin{tabular}{|c|c|c|c|c|c|}
\hline & Castro and Ruiz ${ }^{1}$ & Ohana and Mash ${ }^{4}$ & Paez et $\mathrm{al}^{3}$ & Tajeu et $\mathrm{al}^{2}$ & Thom and Tirado ${ }^{5}$ \\
\hline Conclusion & $\begin{array}{l}\text { - Latina patients prefer } \\
\text { Latina NPs with } \\
\text { training in CC, have } \\
\text { higher education, } \\
\text { and speak Spanish } \\
\text { - Shorter wait time is } \\
\text { number one factor } \\
\text { for Latina patient } \\
\text { satisfaction }\end{array}$ & $\begin{array}{l}\text { - Patient view of provider } \\
\text { CC significantly } \\
\text { correlates with patient } \\
\text { satisfaction (higher the } \\
\text { perceived CC, higher the } \\
\text { satisfaction) } \\
\text { - Lower probability of } \\
\text { conflict when fewer } \\
\text { differences exist } \\
\text { between culture of } \\
\text { provider and patient } \\
\text { - Greater the difference } \\
\text { between perceived CC of } \\
\text { provider and patient, less } \\
\text { likely patient will follow } \\
\text { medical advice } \\
\text { - Poor provider/patient } \\
\text { communication could } \\
\text { negatively impact } \\
\text { satisfaction } \\
\text { - Patient involvement in } \\
\text { care may impact } \\
\text { satisfaction and } \\
\text { perception of provider } \\
\text { CC }\end{array}$ & $\begin{array}{l}\text { - Facilitation of } \\
\text { physician CC } \\
\text { including changing } \\
\text { their actions and } \\
\text { beliefs (as related to } \\
\text { different cultures) } \\
\text { could be important } \\
\text { for physician-patient } \\
\text { relationships }\end{array}$ & $\begin{array}{l}\text { - Interaction with health } \\
\text { care staff can affect } \\
\text { patient satisfaction and } \\
\text { perceived } \\
\text { discrimination } \\
\text { - Patients could benefit } \\
\text { from more courtesy } \\
\text { and patient-centered } \\
\text { care from health staff }\end{array}$ & $\begin{array}{l}\text { - Patient reports of } \\
\text { provider CC may be } \\
\text { more ideal because } \\
\text { more correlated with } \\
\text { processes and results } \\
\text { of care than provider } \\
\text { reports } \\
\text { - Similarities between } \\
\text { measuring physician } \\
\text { CC and } \\
\text { interpersonal ability } \\
\text { - A measure of CC } \\
\text { could be beneficial } \\
\text { with CC training and } \\
\text { implementation in } \\
\text { health field }\end{array}$ \\
\hline
\end{tabular}

Abbreviations: ARSMA-II, Acculturation Rating Scale for Mexican Americans; CC, cultural competence; IAPCC, Inventory to Assess the Process of Cultural Competence Healthcare Professionals; NP, nurse practitioner; PCP, primary care physician; PRPCC, patient-reported provider cultural competency; PSACC, provider self-assessment of cultural competency; PSQ-III, Patient Satisfaction Questionnaire.

\section{References}

1. Castro A, Ruiz E. The effects of nurse practitioner cultural competence on Latina patient satisfaction. J Am Acad Nurse Pract. 2009; 21:278-286. PubMed doi:10.1111/j.1745-7599.2009.00406.x

2. Tajeu GS, Cherrington AL, Andreae L, Holt CL, Halanych JH. "We'll get to you when we get to you": exploring potential contributions of health care staff behaviors to patient perceptions of discrimination and satisfaction. Am J Public Health. 2015;105:2076-2082. PubMed doi:10.2105/AJPH.2015.302721

3. Paez KA, Allen JK, Beach MC, Carson KA, Cooper LA. Physician cultural competence and patient ratings of the patient-physician relationship. J Gen Intern Med. 2009;24:495-498. PubMed doi: 10.1007/s11606-009-0919-7

4. Ohana S, Mash R. Physician and patient perceptions of cultural competency and medical compliance. Health Educ Res. 2015;30: 923-934. PubMed doi:10.1093/her/cyv060

5. Thom DH, Tirado MD. Development and validation of a patientreported measure of physician cultural competency. Med Care Res Rev. 2006;63:636-655. PubMed doi:10.1177/1077558706290946
6. Singh J. Critical appraisal skills programme [serial online]. J Pharmacol Pharmacother. 2013;4:76-77. http://www.jpharmacol.com/ text.asp?2013/4/1/76/107697

7. Michalopoulou G, Falzarano P, Arfken C, Rosenberg D. Physicians' cultural competency as perceived by African American patients. $J$ Natl Med Assoc. 2009;101(9):893-899.

8. Doorenbos AZ, Schim SM, Benkert R, Borse NN. Psychometric evaluation of the cultural competence assessment instrument among healthcare providers. Nurs Res. 2005;54(5):324-331.

9. Sargent S, Sedlack C, Marsolf D. Cultural competence among nursing students and faculty. Nurs Educ Today. 2005;25(3):214-221. PubMed doi:10.1016/j.nedt.2004.12.005

10. Price E, Beach M, Gary T, et al. A systematic review of the methodological rigor of studies evaluating cultural competence training of health professionals. Acad Med. 2005;80(6):578-586. PubMed doi:10.1097/00001888-200506000-00013

11. Marra J, Covassin T, Shingles RR, Canady RB, Mackowiak T. Assessment of certified athletic trainer's level of cultural competence in the delivery of health care. J Athl Train. 2010;45(4):380-385. PubMed doi:10.4085/1062-6050-45.4.380 